\title{
Analisis Kemampuan Komunikasi Matematis Siswa pada Materi Lingkaran ditinjau dari Perbedaan Gender
}

\author{
Sherli Pitrah Dewi ${ }^{1}$, Maimunah ${ }^{2 *}$, Yenita Roza ${ }^{3}$ \\ Program Studi Magister Pendidikan Matematika, \\ Fakultas Keguruan dan Ilmu Pendidikan, Universitas Riau \\ *Corresponding Author. Email: maimunah@ lecturer.unri.ac.id
}

\begin{abstract}
The purpose of this study was to describe mathematical communication skills in the circle material in terms of students' gender differences. This research method is a descriptive method with a qualitative approach. The subjects of this study were students of class VIII at MTsS Madinatun Najah Rengat, Indragiri Hulu Regency, Riau Province, totaling 16 students. The data collection instrument used in this study was a written test. While the data analysis technique used descriptive analysis. The results showed that the mathematical communication skills of female students on all indicators had higher scores than male students. Female students are categorized as good at solving mathematical problems so that they are able to communicate mathematical ideas using pictures or symbols and have better mathematical representations than male students. The mathematical communication ability of female students is higher than the mathematical communication ability of male students with the total average score for female students is $77.8 \%$ and the total average score for male students is $66.7 \%$ or a difference of $11,1 \%$.
\end{abstract}

\begin{abstract}
Abstrak: Tujuan penelitian ini adalah untuk mendeskripsikan kemampuan komunikasi matematis pada materi lingkaran ditinjau dari perbedaan gender siswa. Metode penelitian ini adalah metode deskriptif dengan pendekatan kualitatif. Subjek penelitian ini adalah siswa kelas VIII MTsS Madinatun Najah Rengat, Kabupaten Indragiri Hulu, Provinsi Riau yang berjumlah 16 siswa. Instrument pengumpulan data yang digunakan dalam penelitian ini adalah tes tertulis. Sedangkan teknik analisis datanya menggunakan analisis deskriptif. Hasil penelitian menunjukkan bahwa kemampuan komunikasi matematis siswa perempuan pada semua indikator memiliki nilai lebih tinggi dari siswa laki-laki. Siswa perempuan dikategorikan baik dalam menyelesaikan permasalahan matematika sehingga mampu mengkomunikasikan ide-ide matematika dengan menggunakan gambar atau simbol dan memiliki representasi matematika yang lebih baik dari siswa laki-laki. Kemampuan komunikasi matematis siswa perempuan lebih tinggi dari kemampuan komunikasi matematis siswa laki-laki dengan total nilai rata-rata untuk siswa perempuan yaitu $77,8 \%$ dan total nilai rata-rata untuk siswa laki-laki yaitu $66,7 \%$ atau selisih sebesar $11,1 \%$.
\end{abstract}

\section{Article History}

Received: 05-03-2021

Revised: 10-05-2021

Accepted: 02-07-2021

Published: 07-09-2021

Key Words:

Mathematical

Communication, Circle

Topics, Gender.

\section{Sejarah Artikel}

Diterima: 05-03-2021

Direvisi: 10-05-2021

Disetujui: 02-07-2021

Diterbitkan: 07-09-2021

\section{Kata Kunci:}

Komunikasi Matematis, Materi Lingkaran,

Gender.

How to Cite: Dewi, S., Maimunah, M., \& Roza, Y. (2021). Analisis Kemampuan Komunikasi Matematis Siswa pada Materi Lingkaran ditinjau dari Perbedaan Gender. Jurnal Kependidikan: Jurnal Hasil Penelitian dan Kajian Kepustakaan di Bidang Pendidikan, Pengajaran dan Pembelajaran, 7(3), 699-707. doi:https://doi.org/10.33394/jk.v7i3.3687

https://doi.org/10.33394/jk.v7i3.3687

This is an open-access article under the CC-BY-SA License.

\section{Pendahuluan}

Komunikasi sangat dibutuhkan hampir di seluruh kegiatan manusia, terutama dalam bidang pendidikan. Pendidikan tidak bisa dilaksanakan tanpa adanya dukungan komunikasi, bahkan pendidikan hanya bisa berjalan melalui komunikasi. Hal ini juga berlaku dalam pembelajaran matematika. Dalam pembelajaran matematika, komunikasi menjadi salah satu 
komponen yang sangat penting. Komunikasi diperlukan untuk memahami ide-ide matematika secara benar. Komunikasi matematis itu sendiri merupakan kemampuan untuk mengungkapkan ide atau gagasan matematis baik secara lisan maupun tulisan (Nurmala et al., 2018). NCTM dalam (Hendriana et al., 2017) menyatakan bahwa komunikasi matematis merupakan suatu kemampuan/ kompetensi dasar matematis yang esensial dari matematika dan pendidikan matematika. Tanpa hadirnya komunikasi yang baik, maka perkembangan matematika akan menjadi terhambat. Simbol dalam komunikasi ilmiah dapat berupa tabel, grafik, bagan, gambar persamaan matematika dan lain sebagainya.

Pentingnya kemampuan komunikasi matematis juga ikut diperkuat di dalam tujuan pembelajaran matematika menurut Badan Nasional Standar Pendidikan (BNSP) yaitu agar siswa memiliki keterampilan mengkomunikasikan gagasan dengan simbol, tabel, diagram atau media lainnya guna untuk memperjelas keadaan atau masalah atau dapat pula disebut sebagai kemampuan komunikasi matematis. Dalam lampiran Permendikbud Nomor 21 Tahun 2016 dijelaskan bahwa mata pelajaran matematika salah satunya bertujuan agar siswa memiliki kemampuan mengkomunikasikan gagasan matematika dengan jelas dan efektif. Berdasarkan tujuan pembelajaran matematika nomor lima yang tercantum dalam lampiran Permendikbud Nomor 21 Tahun 2016 tersebut, tampak jelas bahwa komunikasi matematis merupakan salah satu kemampuan penting yang harus dimiliki pada diri siswa. Oleh karena itu, kemampuan komunikasi matematis ini perlu mendapat perhatian.

Menurut NCTM (2000) standar kemampuan komunikasi matematis terdiri dari: 1) kemampuan siswa dalam menjelaskan dan mengungkapkan pemikiran mereka tentang ide matematika secara tertulis ataupun lisan, 2) kemampuan siswa dalam merepresentasikan gambar, diagram, ataupun grafik ke dalam ide matematikanya, dan 3) menggunakan bahasa/ notasi matematika secara tepat dalam berbagai ide matematika. Ansari (2012) menyebutkan indikator-indikator untuk dapat mengukur kemampuan komunikasi matematis siswa yang terbagi dalam tiga kelompok, yaitu: 1) menggambar/drawing, yaitu merefleksikan bendabenda nyata, gambar dan diagram ke dalam ide-ide matematika maupun sebaliknya, yaitu dari ide-ide matematika ke dalam bentuk gambar atau diagram, 2) ekspresi matematika/mathematical expression, yaitu mengekspresikan konsep matematika dengan menyatakan peristiwa sehari-hari dalam bahasa atau simbol matematika, dan 3) menulis/written text, yaitu mengekspresikan jawaban dengan bahasa sendiri, membuat model situasi atau persoalan menggunakan bahasa lisan, tulisan, grafik, dan aljabar, menjelaskan, dan membuat pertanyaan tentang matematika yang telah dipelajari, mendengarkan, kemudian mendiskusikan, dan menulis tentang matematika, lalu membuat konjektur, menyusun argumen, dan generalisasi. Komunikasi matematika yang berjalan dengan baik, tentunya diharapkan dapat membantu siswa untuk memiliki pandangan yang lebih luas tentang matematika dan memiliki sikap logis dan cermat dalam menggunakan matematika untuk menyelesaikan masalah sehari-hari.

Faktor lain yang juga turut mempengaruhi pandangan dan sikap siswa terhadap matematika itu sendiri adalah faktor gender (Fauzan \& Usman, 2018; Annisa et. al., 2021; Adifta et. al.). Perbedaan jenis kelamin (gender) dapat mengakibatkan perbedaan psikologi dalam belajar siswa. Sehingga siswa laki-laki dan perempuan tentu akan memiliki banyak perbedaan dalam mempelajari matematika (Nugraha \& Pujiastuti, 2019). Menurut (Nurfauziah \& Fitriani, 2019) mengungkapkan bahwa perempuan dan laki-laki memiliki keberagaman dalam menyelesaikan suatu masalah matematika termasuk abstraksi matematika. Penyebabnya ialah perbedaan emosional, perilaku, pola pikir serta kecerdasan dari masing-masing pria atau wanita. 
Penelitian (Mz, 2013) menunjukkan terdapat perbedaan kemampuan matematika siswa dari aspek gender. Perbedaanya tersebut dilihat dari kemampuan menyelesaikan soal spatial. Siswa perempuan didapati memiliki pengalaman spatial diluar sekolah yang lebih rendah daripada anak laki-laki, banyak anak perempuan tidak pernah menggali potensinya untuk berpikir secara spatial kecuali jika berpikir spatial diajarkan dalam kurikulum sekolah. Di sisi lainnya, untuk siswa perempuan ternyata mereka lebih unggul dalam hal kemampuan komunikasi (verbal) matematis, lebih termotivasi, terorganisasi dalam belajar dibandingkan anak laki-laki. Hasil penelitian yang dilakukan oleh (Babys, 2020) menunjukkan bahwa kemampuan komunikasi matematika siswa perempuan pada semua indikator memiliki nilai lebih tinggi dari siswa laki-laki. Siswa perempuan secara umum lebih teliti dan cermat dalam menyelesaikan permasalahan matematika sehingga mampu mengkomunikasikan ide-ide matematika baik dengan gambar, diagram atau simbol dan memiliki representasi matematika yang lebih baik dari siswa laki-laki. Kemampuan komunikasi matematika siswa perempuan lebih tinggi dari kemampuan komunikasi matematika siswa laki-laki yaitu sebesar 58,71\% atau selisih $17,42 \%$.

Menurut (Abdussakir \& Achadiyah, 2009) salah satu materi matematika yang sangat lemah diserap oleh siswa adalah lingkaran, disebutkan dalam penelitiannya bahwa kesulitan siswa terjadi saat memahami rumus keliling dan luas lingkaran yang diperoleh hasil masih banyak siswa kelas VIII SMP 6 Kota Mojokerto yang mengalami kesulitan memahami rumus keliling dan luas lingkaran. Jika siswa ditanya berapa keliling atau luas lingkaran yang diketahui jari-jari atau diameternya siswa tidak langsung menjawab, bahkan ada yang mengatakan lupa rumus dan salah menggunakan rumus serta kesulitan siswa ini akan mengakibatkan siswa kesulitan untuk memahami materi selanjutnya seperti kerucut dan tabung. Hal ini akan mengakibatkan tidak maksimalnya proses belajar mengajar.

Pentingnya kemampuan komunikasi matematika pada materi lingkaran dan faktor perbedaan gender yang turut mempengaruhi komunikasi matematika menyebabkan perlunya kajian mendalam tentang bagaimana kemampuan komunikasi metamatika siswa pada materi lingkaran ditinjau dari gender. Adapun tujuan penelitian ini adalah untuk mendeskripsikan kemampuan komunikasi matematis siswa pada materi lingkaran yang ditinjau dari perbedaan gender. Penelitian ini akan memberikan hasil yang lebih spesifik dengan menganalisis kemampuan komunikasi matematis perindikatornya.

\section{Metode Penelitian}

Metode peneltian yang digunakan dalam penelitian ini adalah deskriptif dengan pendekatan kuantitatif. Penelitian ini dilaksanakan di MTsS Madinatun Najah, Kabupaten Indragiri Hulu, Provinsi Riau tahun ajaran 2020/2021. Sumber data dalam penelitian ini adalah siswa kelas VIII sebanyak 16 orang yang terdiri atas 7 orang laki-laki dan 9 orang perempuan. Teknik pengumpulan data yang digunakan adalah tes kemampuan komunikasi matematika.

Indikator komunikasi matematika yang digunakan dalam penelitian ini merujuk dari (Ansari, 2012) disederhanakan menjadi: 1) menggambar/drawing, yaitu menyatakan suatu situasi atau ide-ide matematika ke dalam bentuk gambar, 2) ekspresi matematika/mathematical expression, yaitu menyatakan konsep matematika dengan menyatakan peristiwa sehari-hari dalam model matematis, dan 3) menulis/written text, yaitu menyatakan dan menjelaskan peristiwa sehari-hari dalam bahasa atau simbol matematika. Prosedur penelitiannya melalui beberapa tahapan yaitu: 1) penyusunan soal tes kemampuan komunikasi matematika, 2) memberikan tes dan mengumpulkan hasil tes, 3) menganalisis hasil tes, 4) menarik kesimpulan. Instrumen penelitian yang digunakan pada penelitian ini 
yakni tes kemampuan komunikasi matematis. (Hodiyanto, 2017) mengatakan bahwa soal uraian dapat digunakan untuk mengukur kemampuan komunikasi matematis, seperti soal uraian eksploratif, transfer, elaboratif, dan aplikatif. Sehingga soal yang digunakan pada penelitian ini adalah soal uraian yang terdiri atas 3 soal pada materi lingkaran. Setiap nomor soal mewakili satu indikator kemampuan komunikasi matematika. Soal nomor satu adalah soal kemampuan komunikasi matematis yang memiliki beragam pendapat/ penyelesaian, untuk mengukur indikator komunikasi matematika yang kedua yaitu ekspresi matematika/mathematical expression, menyatakan konsep matematika dengan menyatakan peristiwa sehari-hari dalam model matematis, diadopsi dari soal penelitian terdahulu (Triana, 2020) yang telah divalidasi. Soal nomor dua dan tiga adalah soal kemampuan komunilasi matematis untuk mengukur indikator komunikasi matematika yang pertama dan ketiga, yaitu menggambar/drawing, yaitu menyatakan suatu situasi atau ide-ide matematika ke dalam bentuk gambar dan menulis/written text, yaitu menyatakan dan menjelaskan peristiwa seharihari dalam bahasa atau simbol matematika, diadopsi dari soal penelitian terdahulu (Dewi, 2017) yang telah divalidasi. Adapun data hasil pekerjaan siswa dianalisis menurut gender, dengan menggunakan statistik deskriptif yaitu dengan menghitung nilai rata-rata dan persentase data dari setiap indikator kemudian mendeskripsikan serta menarik kesimpulan dari data yang telah dikumpulkan.

\section{Hasil Penelitian dan Pembahasan}

Hasil tes kemampuan komunikasi matematis yang dilakukan kepada 7 siswa laki-laki dan 9 siswa perempuan, berdasarkan indikator kemampuan komunikasi matematis dan perbedaan gender diperoleh data yang ditampilkan dalam Tabel 1.

Tabel 1. Nilai Kemampuan Komunikasi Matematis Siswa Laki-Laki dan Perempuan

\begin{tabular}{cllcc}
\hline No & \multicolumn{1}{c}{ Aspek } & \multicolumn{1}{c}{ Indikator } & $\begin{array}{c}\text { Nilai Rata-Rata } \\
\text { Perempuan (\%) }\end{array}$ & $\begin{array}{c}\text { Nilai Rata-Rata } \\
\text { Laki-Laki (\%) }\end{array}$ \\
\hline 1 & $\begin{array}{l}\text { Menggambar } \\
\text { (Drawing) }\end{array}$ & $\begin{array}{l}\text { Menyatakan suatu situasi } \\
\text { atau ide-ide matematika ke } \\
\text { dalam bentuk gambar }\end{array}$ & 75 & 71,4 \\
2 & $\begin{array}{l}\text { Ekspresi } \\
\text { matematika } \\
\text { (Mathematical } \\
\text { expression) }\end{array}$ & $\begin{array}{l}\text { Menyatakan konsep } \\
\text { matematika dengan } \\
\text { menyatakan peristiwa } \\
\text { sehari-hari dalam model } \\
\text { matematis }\end{array}$ & 80,6 & 64,3 \\
3 & $\begin{array}{l}\text { Menulis } \\
\text { (Written text) }\end{array}$ & $\begin{array}{l}\text { Menjelakan dan peristiwa } \\
\text { sehari-hari dalam bahasa } \\
\text { atau simbol matematika } \\
\text { Total }\end{array}$ & 77,8 & 64,3 \\
& & & $\mathbf{7 7 , 8}$ & $\mathbf{6 6 , 7}$ \\
\hline
\end{tabular}

Untuk mendeskripsikan kemampuan komunikasi matematis pada materi lingkaran ditinjau dari perbedaan gender, dilakukan analisis yang lebih mendalam terhadap hasil jawaban siswa berdasarkan indikator kemampuan komunikasi matematis ditinjau dari gender siswa, sebagai berikut:

1) Menyatakan suatu situasi atau ide-ide matematika ke dalam bentuk gambar

Berdasarkan data pada Tabel 1 diperoleh bahwa aspek menggambar (drawing) untuk siswa perempuan lebih tinggi dibandingkan dengan siswa laki-laki, terlihat dari persentase nilai rata-rata aspek menggambar (drawing) yaitu $75 \%$ untuk siswa perempuan sedangkan untuk siswa laki-laki persentase nilai rata-ratanya $71,4 \%$ dengan 
perbedaan sebesar 3,6\%. Ada satu komponen indikator pada aspek ini, yaitu menyatakan suatu situasi atau ide matematis ke dalam bentuk gambar.

Dipilih subjek siswa laki-laki dan siswa perempuan pada soal nomor 2 sebagai contoh hasil jawaban siswa. Berikut akan dipaparkan soal dan hasil jawaban siswa. Soalnya adalah "Pak Helmi akan membuat dua buah kolam berbentuk lingkaran, diantara kolam tersebut akan dibuat sebuah jalan sepanjang garis singgung persekutuan dalam kedua kolam tersebut dengan panjang $8 \mathrm{~m}$. Jika kolam pertama mempunyai jari-jari $2 \mathrm{~m}$ dan jarak kedua pusat kolam tersebut adalah $10 \mathrm{~m}$, dimana kolam pertama lebih besar dari kolam kedua. Jelaskan dan gambarkan permasalahan diatas agar lebih mudah dipahami!"
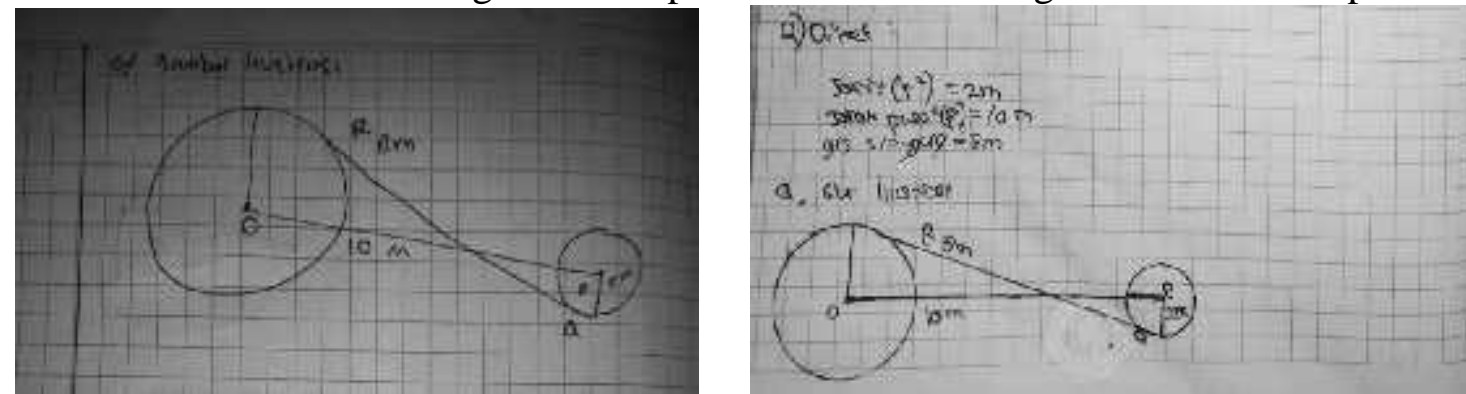

Gambar 1. Jawaban siswa laki-laki No. 2 Gambar 2. Jawaban siswa perempuan No. 2

Dari Gambar 1, terlihat bahwa siswa laki-laki kurang memahami suatu permasalahan pada soal, mereka masih belum mampu menempatkan unsur-unsur yang diketahui dan ditanyakan, sehingga dikatakan kurang mampu menghubungkan ide matematika ke dalam gambar menyebabkan pekerjaan siswa laki-laki kurang sahih atau salah. Hal ini didukung oleh hasil penelitian yang dikemukakan oleh (Minarti \& Nurfauziah, 2016) yaitu siswa mengaggap bahwa menuliskan apa yang diketahui dan apa yang ditanyakan merupakan hal yang tidak penting dan membuang buang waktu. Padahal menuliskan apa yang diketahui dan apa yang ditanyakan merupakan hal yang penting saat menyelesaikan soal, karena dalam menjawab soal uraian bukan hanya mengutamakan jawaban yang benar tetapi juga melihat proses bagaimana cara siswa mengungkapkan ide untuk menyelesaikan soal tersebut. Sedangkan Gambar 2, menunjukkan bahwa siswa perempuan lebih baik dalam memahami apa yang dimaksud pada soal. Hal ini terlihat dari jawaban siswa yang menuliskan unsur-unsur yang diketahui dan ditanyakan, serta menuliskan penyelesaian yang lebih sistematis. Dalam hal ini, siswa perempuan sudah mampu menyatakan suatu situasi atau ide-ide matematika ke dalam bentuk gambar.

2) Menyatakan konsep matematika dengan menyatakan peristiwa sehari-hari dalam model matematis

Pada aspek ekspresi matematika (mathematical expression), untuk siswa perempuan juga masih lebih tinggi dibandingkan siswa laki-laki dengan persentase nilai rata-rata $80,6 \%$ untuk siswa perempuan dan persentase nilai rata-rata untuk siswa laki-laki yaitu $64,3 \%$ dengan perbedaan sebesar 16,3\%. Ada satu komponen indikator pada aspek ini, yaitu menyatakan konsep matematika dengan menyatakan peristiwa sehari-hari dalam model matematis. Dipilih subjek siswa laki-laki dan siswa perempuan pada soal nomor 1 sebagai contoh hasil jawaban siswa. Berikut akan dipaparkan soal dan hasil jawaban siswa. Soalnya adalah "Perhatikan gambar di bawah ini, jika titik $O$ adalah pusat lingkaran, manakah yang merupakan sudut pusat dan berapa besar sudut pusat tersebut? Buat model matematika dari permasalahan tersebut dan sertakan alasanmu!" 


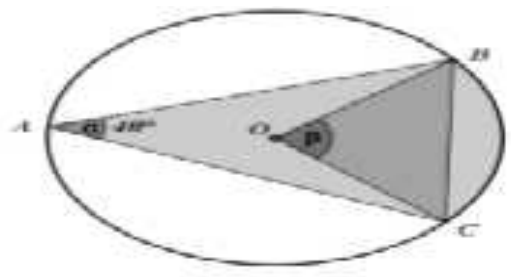

Gambar 3. Soal No. 1
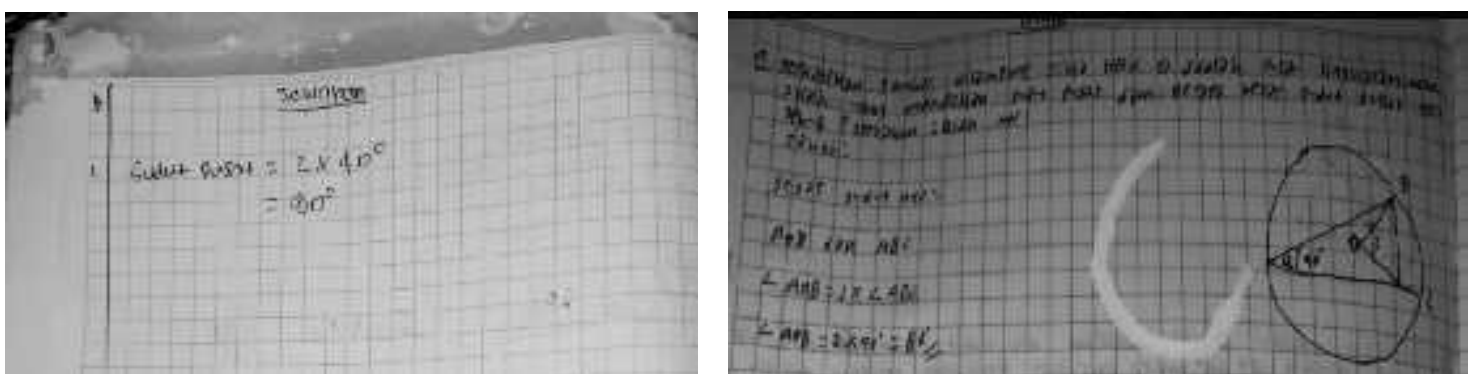

Gambar 4. Jawaban siswa laki-laki No. 1 Gambar 5. Jawaban siswa perempuan No. 1

Dari Gambar 5, terlihat dari hasil jawaban siswa laki-laki yang masih belum mampu dalam menentukan simbol matematis yang mengakibatkkan siswa kesulitan dalam membuat model matematis dari soal yang diberikan. Sedangkan Gambar 5 menunjukkan bahwa siswa perempuan lebih baik dalam memahami apa yang dimaksud pada soal, siswa tersebut mencoba untuk mengerjakannya walaupun dalam hasil akhirnya mereka masih kesulitan dalam memberikan alasan dari jawaban yang dikerjakan. Dengan demikian, siswa perempuan masih lebih tinggi dalam indikator menyatakan konsep matematika dengan menyatakan peristiwa sehari-hari dalam model matematis dari pada siswa laki-laki,.

3) Menyatakan dan menjelaskan peristiwa sehari-hari dalam bahasa atau simbol matematika

Pada aspek menulis (written text), untuk siswa perempuan juga masih lebih tinggi dibandingkan siswa laki-laki dengan persentase nilai rata-rata $77,8 \%$ untuk siswa perempuan dan persentase nilai rata-rata untuk siswa laki-laki yaitu 64,3\% dengan perbedaan sebesar 13,5\%. Ada satu komponen indikator pada aspek ini, yaitu menyatakan dan menjelaskan peristiwa sehari-hari dalam bahasa atau simbol matematika.

Dipilih subjek siswa laki-laki dan siswa perempuan pada soal nomor 3 sebagai contoh hasil jawaban siswa. Berikut akan dipaparkan soal dan hasil jawaban siswa. Soalnya adalah "Pak Helmi akan membuat dua buah kolam berbentuk lingkaran, diantara kolam tersebut akan dibuat sebuah jalan sepanjang garis singgung persekutuan dalam kedua kolam tersebut dengan panjang $8 \mathrm{~m}$. Jika kolam pertama mempunyai jari-jari $2 \mathrm{~m}$ dan jarak kedua pusat kolam tersebut adalah $10 \mathrm{~m}$, dimana kolam pertama lebih besar dari kolam kedua. Selesaikanlah permasalahan matematis tersebut!" 

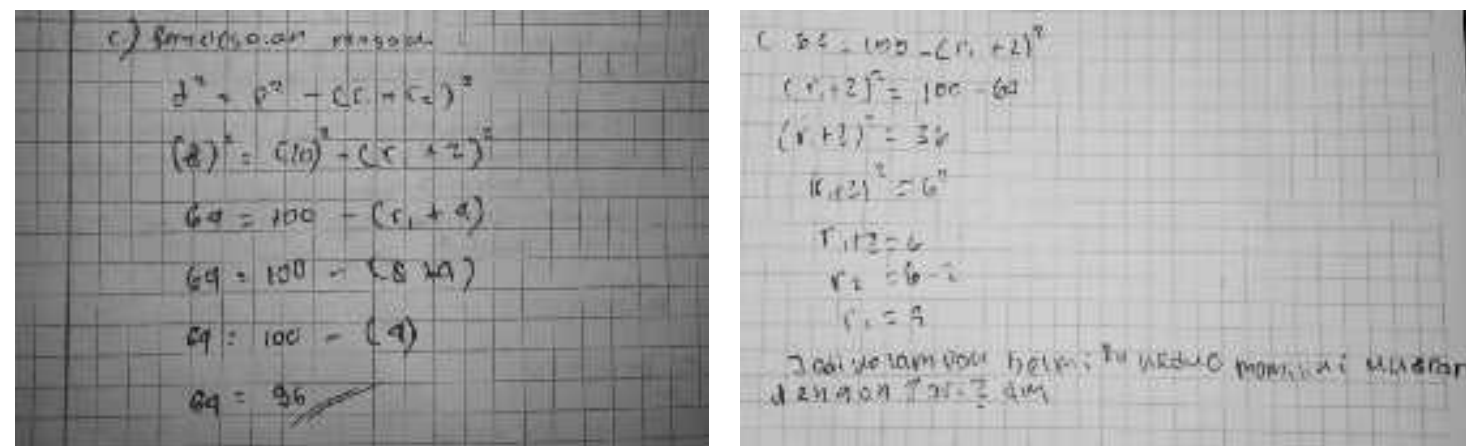

Gambar 6. Jawaban siswa laki-laki No. 3 Gambar 7. Jawaban siswa perempuan No. 3

Dari Gambar 6, terlihat dari hasil jawaban siswa laki-laki kebingungan dalam mengerjakan soal komunikasi matematis yang berkaitan dengan indikator menyatakan dan menjelaskan peristiwa sehari-hari dalam bahasa atau simbol matematika. Hal ini terlihat dari hasil jawaban siswa, siswa sudah berusaha menjawab soal, namun terdapat kekeliruan dalam proses perhitungan soal dan siswa juga belum mampu memberikan kesimpulan akhir dari soal uraian tersebut, permasalahan ini bisa disebabkan karena konsep pemahaman yang dimiliki belum kuat sehingga membuat siswa kurang kepercayaan diri dalam menjawab soal. Hal ini didukung oleh penelitian (Rizqi et al., 2016) dan (Nayazik, 2017) yang mengungkapkan bahwa siswa yang memiliki rasa percaya diri yang baik akan bisa menyampaikan ide-ide matematis baik secara lisan maupun tulisan sehingga dalam beberapa masalah dapat memilih dan menggunakan strategi yang tepat. Sedangkan pada Gambar 7, siswa perempuan sudah mampu menjawab soal dengan benar dan lengkap, rapi dan sesuai urutan. Hal ini sesuai dengan pernyataan dari (Wijaya et al., 2016) yang mengatakan “...subjek gender perempuan pada subjek penelitian cenderung menggunakan langkah yang urut dan sistematis, penulisan rapi serta jelas, kemudian coretan pada jawaban hampir tidak ada, coretan-coretan yang tidak penting juga hampir tidak ada, menulis jawaban dengan cukup lengkap, memperhatikan estetika dan urutan". Dengan demikian, siswa perempuan lebih dominan pada segi kognitif, menjawab soal-soal matematika secara tertulis dengan lengkap dibanding siswa laki-laki.

Secara keseluruhan, kemampuan komunikasi matematis siswa perempuan lebih tinggi dibandingkan siswa laki-laki dengan total nilai rata-rata untuk siswa perempuan yaitu 77,8\% sedangkan total nilai rata-rata untuk siswa laki-laki yaitu $66,7 \%$ dengan perbedaan sebesar 11,1\%. Hal ini didukung dengan hasil penelitian (Prayitno et al., 2013) yang menyatakan bahwa kelengkapan komunikasi matematis siswa bergender perempuan lebih baik dibanding siswa laki-laki. Dalam penelitian ini juga diperoleh hasil yang sama, yaitu kemampuan komunikasi matematis siswa perempuan yang ditinjau dari tiga indikator lebih tinggi dibandingkan siswa laki-laki.

\section{Kesimpulan}

Berdasarkan hasil dari penelitian ini dapat disimpulkan bahwa, kemampuan komunikasi matematis siswa perempuan lebih tinggi dari kemampuan komunikasi matematis siswa lakilaki dengan total nilai rata-rata untuk siswa perempuan yaitu $77,8 \%$ dan total nilai rata-rata untuk siswa laki-laki yaitu $66,7 \%$ atau selisih sebesar $11,1 \%$. Hal ini dapat ditunjukkan dari tingginya ketercapaian pada semua indikator siswa perempuan dari pada siswa laki-laki. Siswa perempuan dikategorikan baik dalam menyelesaikan masalah matematika sehingga mampu mengkomunikasikan ide-ide matematika dengan menggunakan gambar atau simbol dan memiliki representasi matematika yang lebih baik dari siswa laki-laki. 


\section{Saran}

Berdasarkan hasil penelitian ini disarankan kepada guru agar mengupayakan peningkatan kemampuan komunikasi matematika, salah satunya dengan cara memperhatikan gender dan penggunaan metode pembelajaran yang bervariasi misalnya metode demostrasi, tanya jawab dan eksperimen dalam meningkatkan minat dan motivasi belajar siswa laki-laki dan perempuan agar dapat diterapkan solusi belajar yang tepat dan tujuan pembelajaran matematika dapat tercapai, khususnya kemampuan komunikasi matematis siswa.

\section{Daftar Pustaka}

Abdussakir, A., \& Achadiyah, N. L. (2009). Pembelajaran keliling dan luas lingkaran dengan strategi REACT pada Siswa Kelas VIII SMP Negeri 6 Kota Mojokerto. Seminar Nasional Matematika dan Pendidikan Matematika, Universitas Negeri Yogyakarta

Annisa, R., Roza, Y., \& Maimunah, M. (2021). Analisis Kemampuan Pemecahan Masalah Matematis Siswa SMP Berdasarkan Gender. Jurnal Kependidikan: Jurnal Hasil Penelitian dan Kajian Kepustakaan di Bidang Pendidikan, Pengajaran dan Pembelajaran, 7(2), 481-490. doi:https://doi.org/10.33394/jk.v7i2.3688

Adifta, E., Maimunah, M., \& Roza, Y. (2020). Analisis Kemampuan Pemecahan Masalah Siswa Madrasah Tsanawiyah Kelas VII pada Materi Himpunan. Jurnal Kependidikan: Jurnal Hasil Penelitian dan Kajian Kepustakaan di Bidang Pendidikan, Pengajaran dan Pembelajaran, 6(2), 340-348. doi:https://doi.org/10.33394/jk.v6i2.2561

Ansari, B. I. (2012). Komunikasi matematik dan politik. Banda Aceh: Yayasan Pena.

Babys, U. (2020). Analisis Kemampuan Komunikasi Matematika Siswa Ditinjau dari Gender. ANARGYA: Jurnal Ilmiah Pendidikan Matematika, 3(1), 25-29.

Dewi, R. (2017). Pengembangan Instrumen Tes untuk Mengukur Kemampuan Komunikasi Matematis Siswa SMP Negeri 17 Makassar. Skripsi: Fakultas Tarbiyah dan Keguruan Universitas Islam Negeri Alauddin Makassar.

Fauzan, M. R., \& Usman, H. B. (2018). Analisis Kemampuan Komunikasi Matematis Siswa SMP Negeri 4 Palu dalam Memahami Konsep Pecahan Berdasarkan Gender yang Berkemampuan Tinggi. Jurnal Elektronik Pendidikan Matematika Tadulako, 6(1), 88-98.

Hendriana, H., Rohaeti, E. E., \& Sumarmo, U. (2017). Hard skills dan soft skills matematik siswa. Bandung: Refika Aditama.

Hodiyanto, H. (2017). Kemampuan komunikasi matematis dalam pembelajaran matematika. Jurnal AdMathEdu, 7(1), 9-18.

Minarti, E. D., \& Nurfauziah, P. (2016). Pendekatan Konsturktivisme dengan Model Pembelajaran Generatif Guna Meningkatkan Kemampuan Komunikasi dan Koneksi Matematis serta Self Efficacy Mahasiswa Calon Guru di Kota Cimahi. Jurnal Ilmiah P2M STKIP Siliwangi, 3(2), 68-83.

Mz, Z. A. (2013). Perspektif gender dalam pembelajaran matematika. Marwah: Jurnal Perempuan, Agama Dan Jender, 12(1), 15-31.

Nayazik, A. (2017). Pembentukan keterampilan pemecahan masalah melalui model IDEAL problem solving dengan teori pemrosesan informasi. Kreano: Jurnal Matematika Kreatif-Inovatif, 8(2), 182-190.

Nugraha, T. H., \& Pujiastuti, H. (2019). Analisis Kemampuan Komunikasi Matematis Siswa Berdasarkan Perbedaan Gender. Edumatica: Jurnal Pendidikan Matematika, 9(1), 17. 
Nurfauziah, P., \& Fitriani, N. (2019). Gender dan Resiliensi Matematis Siswa SMP dalam Pembelajaran Scientific Berbantuan VBA Excel. Symmetry: Pasundan Journal of Research in Mathematics Learning and Education, 4(1), 28-37.

Nurmala, I., Hidayat, W., \& Hendriana, H. (2018). Meningkatkan Kemampuan Komunikasi Matematik Siswa Sekolah Menengah Pertama Melalui Pendekatan Contextual Teaching and Learning. JPMI : Jurnal Pembelajaran Matematika Inovatif, 1(1), 2128.

Prastiwi Darmastini, D. (2014). Multi Representasi Siswa Smp Dalam Menyelesaikan Soal Terbuka Matematika Ditinjau Dari Perbedaan Gender. MATHEdunesa, 3(1).

Pratiwi, D. D. (2015). Analisis kemampuan komunikasi matematis dalam pemecahan masalah matematika sesuai dengan gaya kognitif dan gender. Al-Jabar: Jurnal Pendidikan Matematika, 6(2), 131-142.

Rizqi, A. A., Suyitno, H., \& Sudarmin, S. (2016). Analisis Kemampuan Komunikasi Matematis Ditinjau dari Kepercayaan Diri Siswa Melalui Blended Learning. Unnes: Journal of Mathematics Education Research, 5(1), 17-23.

Sunarya, L., Kusmayadi, T. A., \& Iswahyudi, G. (2014). Profil Tingkat Berpikir Kreatif Siswa Kelas VII SMP Negeri 16 Surakarta dalam Pemecahan Masalah Aritmatika Sosial ditinjau dari Motivasi dan Gender. Jurnal Pembelajaran Matematika, 1(7).

Triana, C. R. (2020). Analisis Kemampuan Komunikasi Matematis Siswa SMP ditinjau dari Self Confidence Siswa pada Materi Lingkaran. Skripsi: Fakultas Tarbiyah dan Keguruan, Uin Sultan Syarif Kasim Riau.

Wijaya, H. P. I., Sujadi, I., \& Riyadi, R. (2016). Kemampuan Komunikasi Matematis Siswa Sesuai dengan Gender dalam Pemecahan Masalah pada Materi Balok dan Kubus (Studi Kasus pada Siswa SMP Kelas VIII SMP Islam Al-Azhar 29 Semarang). Jurnal Pembelajaran Matematika, 4(9). 